\title{
Oleocellosis Injury of Fruitlets from Late-season Mechanical Harvesting of 'Valencia' Orange Trees after Different Irrigation Treatments Does Not Affect Internal Fruit Quality
}

\author{
Juan Carlos Melgar ${ }^{1,2}$, Jill M. Dunlop, and James P. Syvertsen \\ Citrus Research and Education Center, University of Florida, IFAS, 700 \\ Experiment Station Road, Lake Alfred, FL 33850
}

Additional index words. tree health, oil spotting, sweet orange, canopy shaker, young green fruit

\begin{abstract}
Oleocellosis or oil spotting on the peel of citrus fruit is a common post-harvest injury caused by improper handling. Mechanical injury allows phytotoxic oil to leak out of oil glands and cause injury to surrounding flavedo cells, resulting in oleocellosis. Mechanical harvesting (MH) of 'Valencia' sweet orange is conducted in late spring, when the next season's fruitlets are in their early stages of development. There is a concern that mechanical injury from harvesting machines can cause oleocellosis and fruit drop of young, green 'Valencia' sweet orange fruitlets, especially late in the harvest season when fruitlets are relatively large. We evaluated the effects of winter drought stress and subsequent late-season MH with a canopy shaker on oleocellosis of 'Valencia' sweet orange fruitlets. In April, mature fruit size, juice content, total soluble solids, and acidity were unaffected by previous winter drought stress treatments. Mechanical harvesting removed $\approx 90 \%$ to $95 \%$ of mature fruit and $20 \%$ to $50 \%$ of fruitlets depending on previous drought stress treatments and harvesting date. Beginning 1 week after the late harvest (13 June), attached fruitlets were tagged and visually evaluated approximately every other month to determine oleocellosis injury until the late-season harvest 12 months later. Only $12 \%$ of the fruitlets had oleocellosis on more than $30 \%$ of their surface area. Up to $75 \%$ of the fruitlets from the previously drought-stressed trees had less than $10 \%$ of their surface area injured after MH and $11 \%$ of these fruitlets dropped before harvest. Nonetheless, there was no significant increase in fruit drop with increased surface area injured nor was juice quality affected at harvest. Overall, fruit surface oleocellosis decreased and healed as fruit expanded, but surface blemishes did not completely disappear. Thus, fruitlet oleocellosis in late-season mechanically harvested trees was cosmetic and did not increase fruit drop nor alter internal fruit quality.
\end{abstract}

Mechanical harvesting of citrus fruit for juice processing from large-scale commercial plantings in Florida has economic advantages (Roka et al., 2008) over hand-harvesting, especially when adequate seasonal labor is not available (Brown, 2005; Roka, 2004). The shaking and visible injuries that citrus trees may experience during $\mathrm{MH}$ with trunk or canopy shakers are considered major impediments to the widespread adoption of $\mathrm{MH}(\mathrm{Li}$ and Syvertsen, 2005; Zekri and Syvertsen, 2008). However, bark and branch injuries by canopy shakers are often not worse than injuries from ladders during hand picking operations (Buker et al., 2004), and there tends to be less leaf and twig loss from $\mathrm{MH}$ after the initial year of $\mathrm{MH}$. The most common $\mathrm{MH}$

Received for publication 28 Oct. 2010. Accepted for publication 28 Jan. 2011.

${ }^{1}$ Current address: Citrus Center, Texas A\&M University-Kingsville, $312 \mathrm{~N}$ International Boulevard, Weslaco, TX 78596.

${ }^{2}$ To whom reprint requests should be addressed; e-mail jcmelgar@ag.tamu.edu. injuries in citrus and other fruit trees include leaf loss, twig loss, bark scuffing, flower loss, green immature fruit (fruitlet) drop, and exposure of roots at the soil surface (Halderson, 1966). Nonetheless, there is no evidence that such injuries in healthy well-managed citrus trees lead to any tree loss or decrease in yield from either long-term $\mathrm{MH}$ (7 to 8 years; Hedden et al., 1988; Whitney, 1995) or any other physiological stress associated with $\mathrm{MH}$ when compared with hand-harvested trees $(\mathrm{Li}$ and Syvertsen, 2005). There is a continuing problem in late-season $\mathrm{MH}$ of 'Valencia' sweet orange, however, because fruitlets from the next season's crop may be large enough to be unavoidably removed by the harvesting machine (Burns et al., 2006). Although winter drought stress of 'Valencia' sweet orange trees can effectively delay flowering so that fruitlets are not large enough to be susceptible to $\mathrm{MH}$ (Melgar et al., 2010), there is concern that mechanical injury of fruitlets could lead to subsequent premature fruit drop or lower fruit quality. The effects of late-season MH injury to fruitlets of 'Valencia' sweet orange exposed to previous winter drought stress have not been described.

Oleocellosis, rindspot, or oil spotting of citrus fruit is a common injury of the flavedo (Fawcett, 1916) caused by mechanical injury from hail, wind, and improper handling (Brodrick, 1970; Cahoon et al., 1964; Dodson, 1966). Mechanical injury allows phytotoxic essential oils (and terpenes) to leak out of oil glands and cause injury to surrounding flavedo cells resulting in oleocellosis. The injured superficial tissues dry out and form a thin, cracked scab on the surface of the fruit (Fawcett, 1916) and the injured rind may not continue to develop mature color, leaving a green or pale area where the injury occurred. Oleocellosis can appear on fruit as small as 2 to $3 \mathrm{~cm}$ in diameter (Jamieson et al., 2006) and appears to be greater on fruitlets than on fully colored or mature fruit. This may be a perception only because green damaged areas do not degreen and are more noticeable on fruitlets. We determined how $\mathrm{MH}$ affected green fruitlets from the next season's crop in late-harvested 'Valencia' sweet orange trees. We tested the hypothesis that different irrigation treatments from the previous winter would affect oleocellosis injury, subsequent fruitlet drop, and fruit quality at maturity.

\section{Materials and Methods}

Plant material and growth conditions. The study was conducted at the University of Florida/IFAS Citrus Research and Education Center, Lake Alfred, FL (long. $28.09^{\circ} \mathrm{N}$, lat. $81.73^{\circ} \mathrm{W}$; elevation $51 \mathrm{~m}$ ). Uniform 14-yearold 'Valencia' sweet orange (Citrus sinensis L. Osbeck) trees on 'Swingle' citrumelo (C. paradisi Macfad. $\times$ Poncirus trifoliata $\mathrm{L}$. Raf.) were used. There were 12 experimental plots of 10 trees each that were grown in pairs such that spacing between adjacent trees was $2 \mathrm{~m}$ and $5 \mathrm{~m}$ between pairs of trees within the row; between-row spacing was $7 \mathrm{~m}$. There were three wintertime irrigation treatments in a randomized block design with three replicate blocks of 10 trees each. Treatments began on 13 Dec. 2007 and consisted of 1) no irrigation with rain shelter-covered soil (= drought); 2) no irrigation, no cover (= rain only); and 3) regular microsprinkler irrigation as needed with no cover (rain + irrigation $=$ wellirrigated control). The rain-out shelter groundcover was Tyvek ${ }^{\circledR}$ (Dupont $^{\mathrm{TM}}$, Wilmington, $\mathrm{DE}$ ), which covered the entire soil surface under tree canopies. Treatments were maintained until 21 Mar. 2008 (100 d) after which the Tyvek ${ }^{\circledR}$ covers were removed and all trees were well-irrigated.

Flowering intensity. Flowering intensity was estimated by counting the number of flowers after petal fall within a $0.3 \times 0.6-\mathrm{m}$ square frame placed against the branches of the tree $\approx 1.5 \mathrm{~m}$ from the ground (Ribeiro et al., 2008). Flowers were counted every 2 weeks from the beginning of March to the end of May. Counts were made in three pairs of trees per treatment on 30 shoots per tree, 15 shoots on the east and 15 on the west side of the canopy, within the limits of the frame. The 
total number of flowers and fruitlets on a tree was estimated by extrapolating the flowers counted in the frame to the whole tree canopy surface area, estimated as a prolate spheroid surface minus $10 \%$ to account for the flat bottom (Albrigo et al., 1975).

Harvesting and injury evaluation. Effects of previous irrigation treatments and $\mathrm{MH}$ on fruitlets were compared with fruitlets from hand-harvested trees at the beginning of June 2008. A commercial pull-behind canopy shaker (Model 3210; Oxbo International Corp., Byron, $\mathrm{NY}$ ) was used for $\mathrm{MH}$ in one pair of trees in each treatment and block $(n=3)$. Another pair of trees was hand-harvested in each block $(\mathrm{n}=3)$. Beginning 1 week after harvesting (13 June), oleocellosis injury was evaluated by visual estimations of the percentage of surface area injured on 20 tagged fruitlets randomly selected on each pair of trees (240 fruitlets in total). The same fruitlets were repeatedly evaluated approximately every 2 months on 7 Aug., 17 Oct., and 9 Jan. Visual estimations were confirmed from digital photographs of all selected fruitlets (13 June) and injured surface area was measured using image analysis software (SigmaScan Pro 5.0; SPSS Inc., Chicago, IL). The number of fruitlets missing between measurement dates was used to calculate the percentage of fruit drop in each treatment.

Juice analysis. In April, mature fruit samples of $10 \mathrm{~kg}$ (53 fruits on average) were taken from each pair of hand- and mechanically harvested trees. Sampled fruit were weighed to calculate average fruit size $(\mathrm{g})$ and fruit were juiced in a processing pilot plant using a commercial FMC 291B-100 citrus juice extractor (FMC, Lakeland, FL). Juice content (\%), total soluble solids ( ${ }^{\circ}$ Brix), acidity, and brix:acidity ratio were determined using standard methods approved for Florida orange juice (Kimball, 1999; Wardowski et al., 1995).

Statistical analysis. The effects of previous irrigation treatments and harvesting methods were tested using analysis of variance (SAS 9.1; SAS Institute, Cary, NC). Percentage data were transformed by arcsin and means were separated by Duncan's multiple range test $(P \leq$ $0.05)$.

\section{Results}

Petal fall occurred at the end of March for well-irrigated and rain-only trees, whereas petal fall did not occur until the middle of April for previously drought-stressed trees (Fig. 1). Green fruitlets from hand-harvested trees did not have any visible surface injury, but some injury occurred on most fruitlets on the mechanically harvested trees (Table 1). Overall, only $12 \%$ of the fruitlets had oleocellosis on more than $30 \%$ of their surface; $68 \%$ of the fruitlets had oleocellosis on $10 \%$ or less of their surface. Within each injury class, there was no significant effect of previous drought stress treatments on the percentage of surface injured. Visible peel injuries healed but the dried blemishes did not disappear and still could be observed as fruit approached maturity

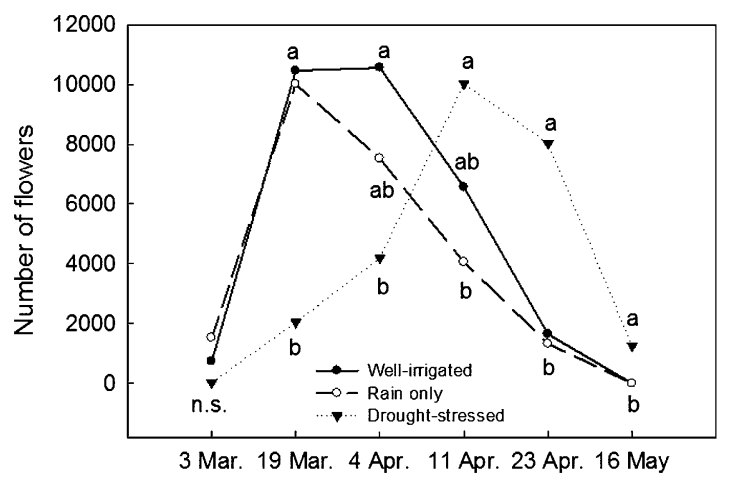

Fig. 1. Effect of previous winter irrigation treatments on the average total number of flowers per tree $(n=6$ trees). Different letters denote significant differences $(P \leq 0.05)$.

Table 1. Estimation of percentage of surface injury with oleocellosis and fruitlet drop for both harvest methods $(n=240)$ and previous winter irrigation treatments. ${ }^{\mathrm{z}}$

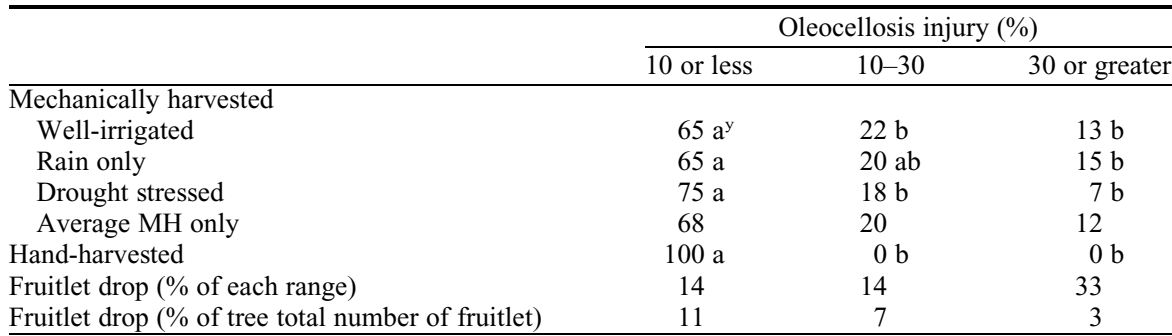

${ }^{z} n=60$ fruitlets per treatment from three replicate pairs of trees.

${ }^{\mathrm{y}}$ Different letters within each irrigation treatment indicate significant differences among the percentage of injury at $P \leq 0.05$. No significant differences were found among different treatments for the same percentage of injury.

$\mathrm{MH}=$ mechanically harvested.

the next year. The percentage of surface injury remained relatively constant as fruitlets from the drought-stressed and rain-only treatments expanded, whereas the percentage of injury decreased after October on fruitlets from the previously well-irrigated treatment to levels significantly lower than in drought-stressed trees (Fig. 2). Percentage of fruitlet drop was as high as $33 \%$ among the fruitlets with surface area injury over $30 \%$ (Table 1 ). However, this percentage of surface injury and fruitlet drop only accounted for $3 \%$ of the total number of fruitlets in the entire canopy. In addition, there was no increase in fruitlet drop with increased surface area injured. Although $14 \%$ of the fruitlets with a percentage surface injury below $30 \%$ dropped, this accounted for only $18 \%$ $(11 \%+7 \%)$ of the total fruitlets in the canopy. The percentage of fruitlet drop was calculated considering both mechanical harvesting and hand-harvesting, but this counts only fruitlets with damage less than $10 \%$ because handharvested trees did not have fruitlets with oleocellosis injury greater than $10 \%$. Previous irrigation treatment did not affect fruitlet drop after mechanical harvesting; fruitlet drop accounted for $20 \%, 25 \%$ and $17 \%$ for droughtstressed, rain-only, and well-irrigated trees, respectively.

In April, fruit on previously well-irrigated trees tended to be larger than on other treatments, but previous irrigation treatment or harvesting method did not significantly affect fruit size, juice content, total soluble solids, or acidity of mature fruit (Table 2).

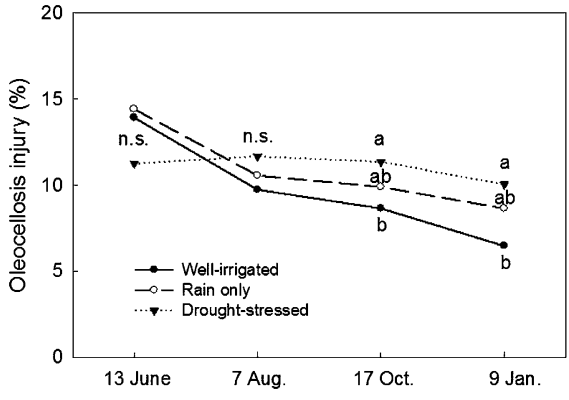

Fig. 2. Effect previous irrigation treatments on percentage of surface area with oleocellosis injury on fruitlets after mechanical harvesting. Each symbol represents an average of 60 fruitlets from three replicate pairs of trees. Different letters denote significant differences $(P \leq 0.05)$.

\section{Discussion}

Overall, late-season $\mathrm{MH}$ removed an average of $21 \%$ of fruitlets (Table 1 ; sum of average fruitlet drop for each range). Abrasive injuries on fruitlets from $\mathrm{MH}$ appeared similar to fruitlets injured by windscar (Brodrick, 1970; Dodson, 1966). In June, fruitlets on drought-stressed trees were still smaller than those from previously well-irrigated trees and, consequently, were not as susceptible to fruitlet drop caused by MH (Melgar et al., 2010). In addition, the initial percentage of injury on the smaller fruitlets on previously drought-stressed trees was less than in those 
Table 2. Effect of harvesting method and previous irrigation treatment on mature fruit size, juice content, acidity, ${ }^{\circ}$ Brix, and Brix/acidity ratio. ${ }^{z}$

\begin{tabular}{|c|c|c|c|c|c|}
\hline & Fruit size $(\mathrm{g})$ & Juice $(\%)$ & Acidity & Brix & $\overline{\text { Brix/acidity }}$ \\
\hline \multicolumn{6}{|c|}{ Mechanically harvested } \\
\hline Well-irrigated & 196.9 & 57.0 & 0.79 & 13.1 & 16.6 \\
\hline Rain only & 163.8 & 55.7 & 0.88 & 14.3 & 16.3 \\
\hline Drought-stressed & 175.6 & 50.7 & 0.96 & 13.8 & 14.5 \\
\hline Hand-harvested & 187.3 & 57.7 & 0.79 & 14.1 & 17.8 \\
\hline$P$ & $0.49^{y}$ & 0.07 & 0.11 & 0.24 & 0.08 \\
\hline
\end{tabular}

on the well-irrigated or rain-only trees. Because the previous drought stress delayed flowering $\approx 2$ to 3 weeks, fruitlet injury occurred when fruitlets were $\approx 8$ weeks old on the drought-stressed trees and at $\approx 11$ weeks old after anthesis for the well-irrigated and rain-only trees. This probably affected the different injury patterns observed in the different treatments because the stage of fruit development can influence blemish development (Freeman, 1976). In this case, injuries that occurred within 8 weeks of petal fall were smooth, translucent or fine textured, and corky, whereas blemishes initiated 8 to 12 weeks from petal fall were reported to be more corky and scabby in appearance with no regular margins. Usually no further blemishes occurred later than 12 weeks from petal fall when the fruit were 4 to $5 \mathrm{~cm}$ in diameter.

Fruit surface oleocellosis injury decreased as fruit expanded and there was no spreading of existing blemishes. Fruit size on droughtstressed trees caught up with the well-irrigated trees by December (Melgar et al., 2010), but the percentage of surface injury in droughtstressed trees did not decrease as much as in fruitlets from well-irrigated trees. Mechanical wounding of the flavedo of mature fruit is well known to trigger ethylene production and initiate fruit abscission (Evensen et al., 1981; Wang et al., 2002). Wounding flavedo of 2week-old fruitlets can cause $33 \%$ of fruitlet drop, but reductions in fruit detachment force or increases in fruit drop were not observed when 8- to 12-week-old fruitlet were wounded (Kostenyuk and Burns, 2004). The application of a fruit-loosening abscission agent may allow shaking time and intensity to be reduced during MH (Burns et al., 2006) and, consequently, reduce the oleocellosis injuries to the small fruitlets. Also, deficit irrigation in winter to delay flowering in 'Valencia' sweet orange trees destined for late-season MH can reduce the size of fruitlets at harvest (Melgar et al., 2010), thereby reducing initial injury.

Because fruit yields were similar across previous irrigation treatments (Melgar et al., 2010 ), an average of $7 \%$ to $11 \%$ of injured fruitlets followed by an average of $14 \%$ fruitlet drop was not statistically significant. Because previous harvesting method or previous irrigation treatment during winter did not cause any differences in final fruit size or juice quality, oleocellosis on the fruitlets caused only a superficial cosmetic injury that was not important for fruit destined for processing.

In summary, some differences were observed among irrigation treatments in percentage of surface injury, but oleocellosis injury in fruitlets decreased as fruit grew. Fruitlet oleocellosis in late-season mechanically harvested trees did not alter juice quality or increase fruit drop enough to decrease final yields. These results should reduce concerns about oleocellosis and any subsequent fruitlet drop caused by harvesting machines.

\section{Literature Cited}

Albrigo, L.G., C.A. Anderson, G.J. Edwards, F.W. Bistline, W.J. Hepburn, and T. Cary. 1975. Yield estimation of 'Valencia' orange research plots and groves. Proc. Fla. State Hort. Soc. 88 : 44-49.

Brodrick, H.T. 1970. Investigations into blemishes on citrus fruits. S. Afr. Citrus J. 441:7-31.

Brown, G.K. 2005. New mechanical harvesters for the Florida citrus juice industry. HortTechnology 15:69-72.

Buker, R.S., J.P. Syvertsen, J.K. Burns, F.M. Roka, W.M. Miller, M. Salyani, and G.K. Brown. 2004. Mechanical harvesting and tree health. EDIS \#HS961. Univ. FL-IFAS Ext. Publ.

Burns, J.K., F.M. Roka, K.-T. Li, L. Pozo, and R.S. Buker. 2006. Late season 'Valencia' orange mechanical harvesting with an abscission agent and low frequency harvesting. HortScience 41 : 660-663.
Cahoon, G.A., B.L. Grover, and I.E. Eaks. 1964 Cause and control of oleocellosis on lemons. Proc. Amer. Soc. Hort. Sci. 84:188-198.

Dodson, P.G.C. 1966. Injury to citrus fruits by wind. S. Afr. Citrus J. 393:5-7, 11.

Evensen, K.B., M.G. Bausher, and R.H. Biggs. 1981. Wound-induced ethylene production in peel explants of 'Valencia' orange fruit. HortScience 16:43-44.

Fawcett, H.S. 1916. A spotting of citrus fruit due to the action of oil liberated from the rind. Calif. Agr. Exp. Sta. Bull. 266:259-270.

Freeman, B. 1976. Rind blemish of Citrus. I. Initiation and development. Sci. Hort. 1:317327.

Halderson, J.L. 1966. Fundamental factors in mechanical cherry harvesting. Trans. Amer. Soc. Agr. Eng. 9:681-684.

Hedden, S.L., D.B. Churchill, and J.D. Whitney. 1988. Trunk shakers for citrus harvesting. Part II: Tree growth, fruit yield and removal. Appl. Eng. Agr. 4:102-106.

Jamieson, L.E., A. Harty, D. Zivkovic-Brady, R.A. Fullerton, and P. Ramankutty. 2006. Investigations into the major causal agent of rindspot on lemons. N. Z. Plant Prot. 59:34-41.

Kimball, D.A. 1999. Citrus processing: A complete guide. 2nd Ed. Aspen Pub., Gaithersburg, MD. p. 191-246.

Kostenyuk, I.A. and J.K. Burns. 2004. Mechanical wounding and abscission in citrus. Physiol. Plant. 122:354-361.

Li, K.-T. and J.P. Syvertsen. 2005. Mechanical harvesting has little effect on water status and leaf gas exchange in citrus trees. J. Amer. Soc. Hort. Sci. 130:661-666.

Melgar, J.C., J.M. Dunlop, L.G. Albrigo, and J.P. Syvertsen. 2010. Winter drought stress can delay flowering and avoid immature fruit loss during late-season mechanical harvesting of 'Valencia' oranges. HortScience 45:271-276.

Ribeiro, R.V., G.S. Rolim, F.A. de Acevedo, and E.C. Machado. 2008. 'Valencia' sweet orange tree flowering evaluation under field conditions. Sci. Agr. (Piracicaba, Braz.) 65:389-396.

Roka, F.M. 2004. Dollars and cents of mechanical harvesting. Citrus Ind. 85:20-21.

Roka, F.M., J.K. Burns, J.P. Syvertsen, and R. Ebel. 2008. Benefits of an abscission agent in mechanical harvesting of Citrus. Univ. FL-IFAS Ext. Publ. \#FE752.

Wang, K.L.-C., H. Li, and J.R. Ecker. 2002. Ethylene biosynthesis and signaling networks. Plant Cell 14:S131-S151.

Wardowski, W., J. Whigham, W. Grierson, and J. Soule. 1995. Quality test for Florida citrus. Univ. of Florida, Coop. Ext. Service, SP99.

Whitney, J.D. 1995. A review of citrus harvesting in Florida. Trans. Citrus Eng. Conf. 41: $33-60$.

Zekri, M. and J.P. Syvertsen. 2008. A healthy harvest. Florida Grower. 10:24-25. 